\title{
Association of New Single Nucleotide Polymorphism with Type 2 Diabetes Mellitus
}

\author{
Alice Jaya Pradha Cheekurhty ${ }^{1 *}$, Rambabu $C^{2}$ and Amit Kumar ${ }^{3}$
}

${ }^{1}$ Research Scholar, Department of Biochemistry, Acharya Nagarjuna University, India

${ }^{2}$ Professor, Acharya Nagarjuna University, India

${ }^{3}$ CEO, Bio-axis DNA Research Centre, India

\begin{abstract}
Type 2 Diabetes Mellitus is accounting for more than $90 \%$ of all the forms of diabetes. Different genetic epidemiological studies show that the genetic variations in several candidate genes are associated with the increased risk for Type 2 Diabetes Mellitus (T2DM) and related complications in different human populations. Genetic and nongenetic risk factors can foretell the risk of a person to the type 2 diabetes mellitus or become the reason behind diabetes in the person. The main aim of the present work is to evaluate the genetic and non genetic risk factors. Several genetic variants in different candidate genes are suggested for their role in development and advancement of the disease. For the accomplishment of our objective to evaluate genetic risk factors, the previously reported single nucleotide polymorphisms (SNPs) of the candidate genes for type 2 diabetes mellitus and related complications in the Indian and the worldwide population were studied. These were selected because of their proven role in predicting them. The study has revealed the presence of Single Nucleotide Polymorphisms in new positions in three of the genes in the validation process in discrete diabetic population of Andhra Pradesh and Telangana states in India.
\end{abstract}

Keywords: Prevalence; Single nucleotide polymorphisms; Genetic variants; Candidate genes; Type 2 Diabetes Mellitus (T2DM); Complications

\section{Introduction}

Several Genetic, Environmental and Biochemical risk factors interplay together for its development and advancement of T2DM [1]. Type 2 Diabetes Mellitus (T2DM) is a polygenic multifactorial, disorder characterized by chronic elevation of blood glucose levels [2]. T2DM itself is a disease and is a risk factor for complications that leads to increased disability and reduced life span They will be a burden not only on the family but also on the society and health care resources. When the insulin hormone produced by the pancreas could not be effectively used by the body (insulin resistance) [3,4] or the pancreas unable to produce enough insulin hormone (insulin deficiency) [5] or both of them together lead to hyperglycemic conditions. Hence the blood sugar levels cannot be regulated [6,7]. About 387 million people worldwide are affected by diabetes and the count will be raised to 529 million by 2035 with 179 million people with diabetes are undiagnosed (Diabetes Atlas-update-2014) with more than $80 \%$ of diabetic deaths occurring in low- and middle-income groups. This disease was designated as the disease of middle aged and elderly but it is affecting the Adolescents as well as the children [8]. According to recent estimation (2014) of WHO $9 \%$ of adults of 18 years and older had diabetes. The three P's or the common symptoms are Polyuria (Excess urination). Polyphagia (Excess appetite) and Polydipsia (Excess thirst)

So far many genes and various loci are identified by gene linkage and candidate gene association studies have the outcome of T2DM and related complications. Candidate gene study [9] is a pretty good method for assessment of common diseases. The main aim of the study is therefore to validate the presence of previously reported single nucleotide polymorphisms in Calpain 10 (CAPN10) [10-13], Adiponectin (ADIPOQ) [14], Apolipoprotein C-III (APOC III) [1517], Angiotensinogen (AGT) [18-23], Apolipoprotein E (APOE) [2426] and Toll-Like Receptor 4(TLR4) [27] for association with Type 2 Diabetes mellitus and related complications. These SNPs are the reason for development and advancement of diabetes in the person and is a genetic risk factor which predicts the outcome of disease in normal person $[28,29]$.

\section{Materials and Methods}

\section{Materials}

The study intends to detect the risk factors (genetic and non-genetic) which predict the outcome of T2DM and related complications.

The peripheral blood samples were collected from diabetic patients and normal subjects. They were aged between 15 to 85 years. The study is carried out with 180 subjects out of them 96 were females and 84 were males ( 90 subjects are diabetic cases and 90 are controls). The left over blood was collected after taking their consent. Each of them was subjected to a simple questionnaire. The samples were then collected in sitting position in the non-EDTA vials in accordance to the protocol for DNA isolation.

The case subjects of the study were established diabetic patients. The blood samples were primarily screened for diabetes with a simple biochemical test. The biochemical test reports showed Fasting Blood Sugar value of more than $126 \mathrm{mg} / \mathrm{dL}$ and Post Prandial Blood Sugar value of more than $200 \mathrm{mg} / \mathrm{dL}$ in accordance to WHO recommended criteria for diabetes diagnosis. The healthy subjects with no family history of diabetes served as controls.

*Corresponding author: Alice JayaPradha Cheekurhty, Research Scholar Department of Biochemistry, Acharya Nagarjuna University, India, Tel: 9581771118 E-mail: alicejaya@gmail.com

Received February 07, 2015; Accepted March 24, 2015; Published March 30 2015

Citation: Cheekurhty AJP, Rambabu C, Kumar A (2015) Association of New Single Nucleotide Polymorphism with Type 2 Diabetes Mellitus. J Diabetes Metab 6: 530 doi:10.4172/2155-6156.1000530

Copyright: (c) 2015 Cheekurhty AJP, et al. This is an open-access article distributed under the terms of the Creative Commons Attribution License, which permits unrestricted use, distribution, and reproduction in any medium, provided the original author and source are credited. 
Citation: Cheekurhty AJP, Rambabu C, Kumar A (2015) Association of New Single Nucleotide Polymorphism with Type 2 Diabetes Mellitus. J Diabetes Metab 6: 530. doi:10.4172/2155-6156.1000530

Page 2 of 5

Subjects suffering from other infectious diseases were excluded from the study. They were either motivated or prescribed by the doctor for screening of diabetes.

\section{Methods}

Selection of polymorphism in candidate genes: The previously reported SNPs of candidate genes, CAPN10, ADIPOQ, DKK1, APOC-III, AGT, APOE and TLR4 selected for the study are listed with polymorphisms and reference sequence in Table 1 All the candidate genes have proven association with T II D along with related complications [30].

SNPs study: The Leucocyte component of the blood samples were processed for extraction and purification of Genomic DNA using modified Sambrook et al. protocol $[31,32]$. The wash buffer (Tris HCL $\mathrm{pH}=7.5$ ) was used to separate other blood components from the Leucocytes. The Blood proteins were lysed using lysis buffer and proteinase while giving brief heat treatment at $65^{\circ} \mathrm{C}$. The lysed proteins are precipitated using sodium acetate. The DNA is isolated as precipitant in alcohol is purified. The portion gene specific for single nucleotide Polymorphisms is specifically amplified by Polymerase chain reaction (PCR) $[33,34]$. The conditions were optimized for PCR of each of the seven genes. The PCR was done using specially designed primers by us using Primer 3 Blast tool for the purpose of amplification. The amplification was done for both the case and control samples. The amplified PCR products were analyzed qualitatively by agarose gel electrophoresis $[35,36]$ and visualized and photographed in transilluminator after staining with ethidium bromide as shown in Figure 1. These amplified sequences were than subjected to sequencing by Sanger sequencing method [37].

The sequenced portion of the genes in the T2DM patients and normal subjects were analyzed by using different computational tools for: Validation of previously reported SNPs of our samples, Phylogenic similarity and identification of conserved regions.

\section{Results}

The photograph of the seven amplified genes sequence is shown below (Figure 1).

On analysis of sequence stretch of amplified by PCR we found SNPs in the locations other than those reported in the literature of genetic and epidemiological studies. These are in 240592222, 52316022, 11708205 positions of Calpain 10, Dickkopf WNT signaling pathway inhibitor 1 and Toll-Like Receptor 4 genes respectively.

The Phylogenic similarity of genes among different species of organisms was validated using pair wise sequence alignment using CLUSTEL W [38]. This similarity is shown in the Table 2 shown below. The rooted dendrogram of one of the genes Calpain 10 is shown below in Figure 2.

The highly conserved regions among the test samples and

\begin{tabular}{|c|l|l|}
\hline GENE & RERENCE SEQUENCE & Reported SNP \\
\hline CAPN10 & rs2975760, rs3792267 & $\mathrm{C} \rightarrow \mathrm{T}, \mathrm{A} \rightarrow \mathrm{G}$ \\
\hline ADIPOQ & rs1501299, rs3774261, rs2241767 & $\mathrm{C} \rightarrow \mathrm{A}(\mathrm{REV}), \mathrm{A} \rightarrow \mathrm{G}, \mathrm{A} \rightarrow \mathrm{G}$ \\
\hline $\mathrm{DKK} 1$ & $\mathrm{rs} 1569198$ & $\mathrm{~A} \rightarrow \mathrm{G}$ \\
\hline APOC III & rs121918381 & $\mathrm{A} \rightarrow \mathrm{G}$ \\
\hline AGT & rs699 & $\mathrm{C} \rightarrow \mathrm{T}(\mathrm{REV})$ \\
\hline APOE & rs429358 & $\mathrm{C} \rightarrow \mathrm{T}$ \\
\hline TLR4 & rs1927911 & $\mathrm{C} \rightarrow \mathrm{T} \mathrm{G} \rightarrow \mathrm{A}$ \\
\hline
\end{tabular}

Table 1: Single Nucleotide Polymorphisms examined for the validation.

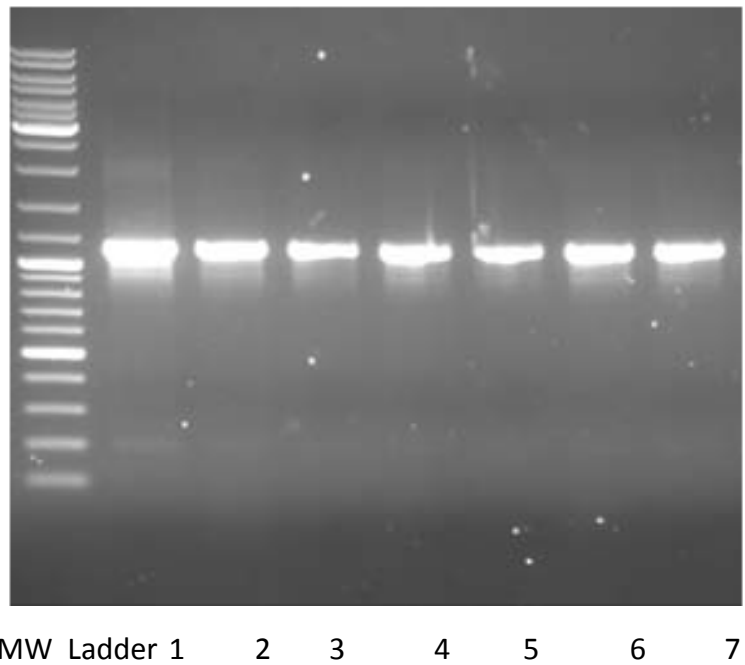

Figure 1: Gel picture for seven genes.

\begin{tabular}{|c|c|}
\hline Organism & Blast Result \\
\hline $\begin{array}{c}\text { Homo sapiens } \\
\text { (test) }\end{array}$ & $\begin{array}{c}\text { Score } 963 \text { bits } \\
\text { Expect0.0 } \\
\text { Identities523/524(99\%) }\end{array}$ \\
\hline Mus musculus & Score 152 bits(82) \\
& Expect4e-39 \\
Identities $225 / 291(77 \%)$ \\
\hline Rattus norvegicus & Score 176 bits(95) \\
& Expect2e-46 \\
\hline Macaca mulatta & Identities $123 / 137(90 \%)$ \\
\hline & Score 643 bits(348) \\
& Expect 0.0 \\
\hline
\end{tabular}

Table 2: Result of query sequence BLAST with different model organisms.

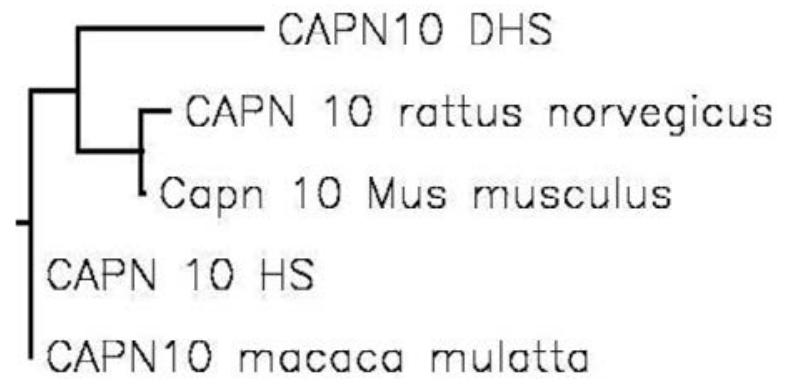

Figure 2: The phylogenetic relationship is shown be the dendrogram.

model organisms is based on the identities in the pair wise sequence alignment. These are shown by BOX SHADE [39]. The BOX shade of highly conserved regions in CAPN10 are shown as an example for highly conserved regions that are shown by green color and Cyan color show least conserved regions (Figures 3 and 4).

The KEGG orthology shows association of the candidate genes with a disease.

The Sequence analysis by BLAST [40] showed that genome sequence of the control and cases have 99\% similarity showing that there is some point mutation and that can be attributed to T2DM. With other organism only CAPN 10 showed results. 
Citation: Cheekurhty AJP, Rambabu C, Kumar A (2015) Association of New Single Nucleotide Polymorphism with Type 2 Diabetes Mellitus. J Diabetes Metab 6: 530. doi:10.4172/2155-6156.1000530

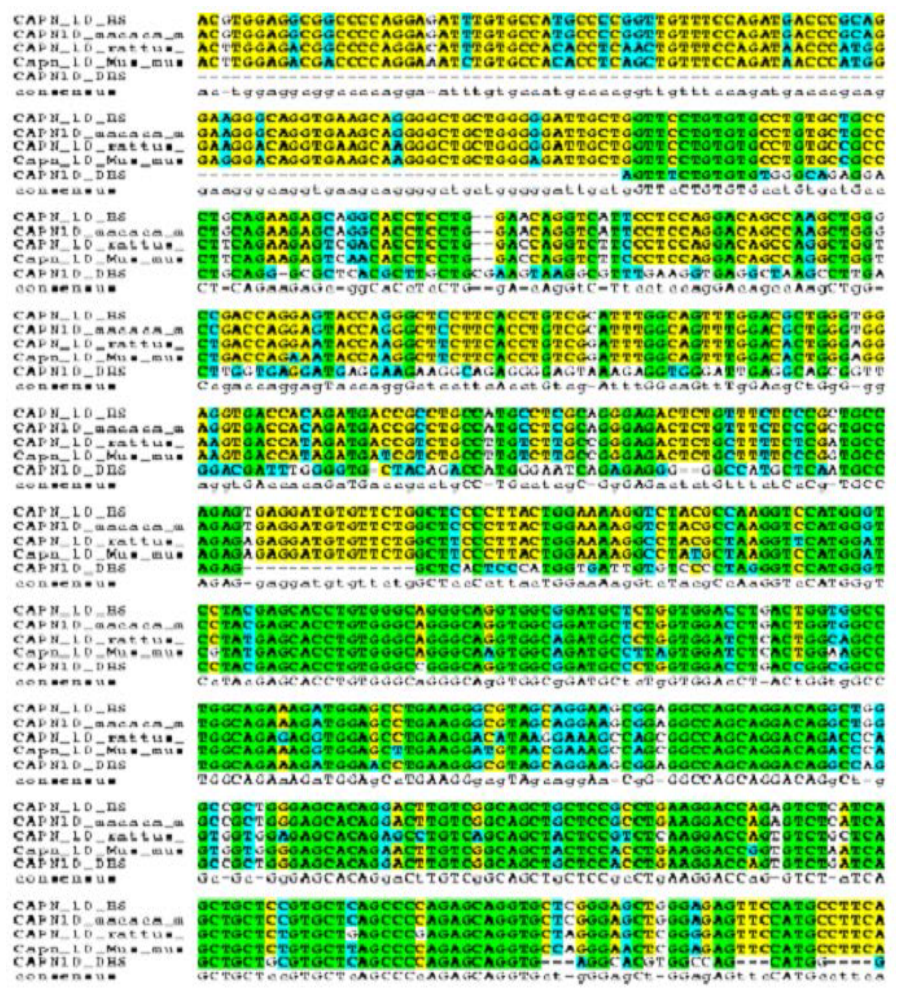

Figure 3: Conserved region shown by Box Shade.

\begin{tabular}{|c|c|c|}
\hline intry & 20100! & Nulinks \\
\hline lene name & CAPH10, CANPLO, IIDNM & Corolore (3) \\
\hline \multicolumn{2}{|c|}{ lefinition calpass 10} & TOE BRI \\
\hline Irthology & 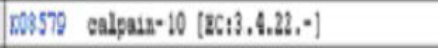 & 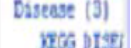 \\
\hline rgganim & 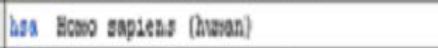 & and (2) \\
\hline lisease & g00409 Type II diabetes mellitus & Cencute [1] \\
\hline Irite & 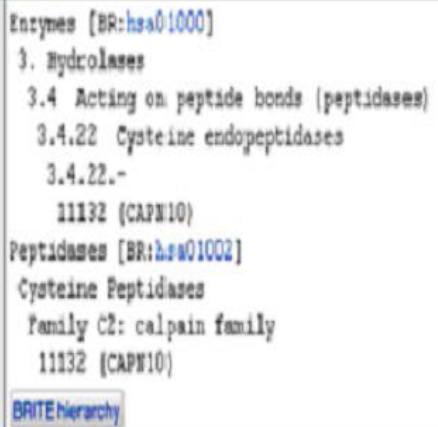 & 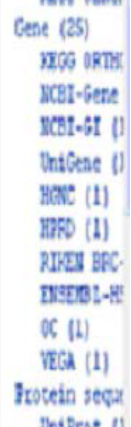 \\
\hline ISDB & Qforogeg Pralog OfI & 9า13-160 \\
\hline lotif & $\begin{array}{l}\text { Pfas: Peptadase_Cl Calpast__III } \\
\text { Wou }\end{array}$ & $\begin{array}{l}\text { Das sequence } \\
\text { retierifey }\end{array}$ \\
\hline thex wi & 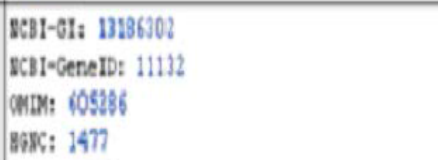 & 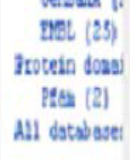 \\
\hline
\end{tabular}

Figure 4: Association of Calpain 10 gene with Type 2 diabetes mellitus. 


\section{Conclusion}

The presence of the previously reported SNPs in the candidate genes are successfully validated in most of the discrete diabetic population of Andhra Pradesh and Telangana states in India. As a finding of this study, we report the presence of SNPs in new positions in three out of the seven genes studied. Sequencing also revealed SNP mutations Ser to Gly $(\mathrm{G} \rightarrow \mathrm{A})$ in new position 240592222 of Calpain-10 gene, Leu to Phe $(\mathrm{C} \rightarrow \mathrm{T})$ in Dickkopf WNT signaling pathway inhibitorland Glu to Gly $(A \rightarrow G)$ in Toll-Like Receptor4. This SNP in new position can be further validated for association with T2DM by extending the study by further analyses to a large-scale association studies on a larger sample size. This is required for establishing a conclusive association of newly identified gene polymorphisms in in Dickkopf WNT signaling pathway inhibitor 11, Calpain 10, and Toll-Like Receptor 4 genes in prediction of genetic risk for Type 2 Diabetes Mellitus.

\section{Acknowledgement}

I would like to thank all the participants of the study. They are no conflicts of interest.

\section{Future Directions}

The conclusive association of new SNPs reported in diabetic population of Andhra Pradesh and Telangana given by extension further analyses on a larger sample size.

\section{References}

1. Cheekurthy AJ, Rambabu C, Kumar A, Surendrababu K (2015) Predisposition factors of T II Diabetes Mellitus and related complications, Biotechnology and Bioforensics. Springer, Singapore. pp 43-50.

2. Lindgren CM, Nilsson A, Orho-Melander M, Almgren P, Groop LC (2001) Characterization of the annexin I gene and evaluation of its role in type 2 diabetes. Diabetes 50: 2402-2405.

3. O'Doherty R, Stein D, Foley J (1997) Insulin resistance. Diabetologia 40 Suppl 3: B10-15.

4. Lillioja S, Mott DM, Spraul M, Ferraro R, Foley JE, et al. (1993) Insulin resistance and insulin secretory dysfunction as precursors of non-insulindependent diabetes mellitus. Prospective studies of Pima Indians. N Engl J Med 329: 1988-1992.

5. Temple RC, Carrington CA, Luzio SD, Owens DR, Schneider AE, et al. (1989) Insulin deficiency in non-insulin-dependent diabetes. Lancet 1: 293-295.

6. World Health Organization (2015). Fact Sheet No.312: What is Diabetes?

7. WHO (1999) Definition, diagnosis and classification of diabetes mellitus and its complications. Part 1: Diagnosis and classification of diabetes mellitus. World Health Organization, Geneva.

8. Singh S (2011) The genetics of Type 2 diabetes mellitus: a review. J Sci Res 55: $35-48$.

9. Yoon PW (2005) Risk Prediction for Common Diseases. La L Rev 66: 33.

10. Bodhini D, Radha V, Ghosh S, Sanapala KR, Majumder PP, et al. (2011) Association of calpain 10 gene polymorphisms with type 2 diabetes mellitus in Southern Indians. Metabolism 60: 681-688.

11. Kommoju UJ, Maruda J, Kadarkarai Samy S, Irgam K, Kotla JP, et al. (2014) Association of IRS, CAPN10, and PPARG gene polymorphisms with type 2 diabetes mellitus in the high-risk population of Hyderabad, India. J Diabetes 6: 564-573.

12. Horikawa Y, Oda N, Cox NJ, Li X, Orho-Melander M (2000) Genetic variation in the gene encoding calpain-10 is associated with type 2 diabetes mellitus. Nat Genet 26: 163-175.

13. Hoffstedt J, Rydén M, Löfgren P, Orho-Melander M, Groop L, et al. (2002) Polymorphism in the Calpain 10 gene influences glucose metabolism in human fat cells. Diabetologia 45: 276-282.

14. Cox NJ (2001) Challenges in identifying genetic variation affecting susceptibility to type 2 diabetes: examples from studies of the calpain-10 gene. Hum Mol Genet 10: 2301-2305.
15. Ramya K, Ayyappa KA, Ghosh S, Mohan V, Radha V (2013) Genetic association of ADIPOQ gene variants with type 2 diabetes, obesity and serum adiponectin levels in south Indian population. Gene 532: 253-262.

16. Stocks J, Holdsworth G, Galton D (1979) Hypertriglyceridæmia associated with an abnormal triglyceride-rich lipoprotein carrying excess Apolipoprotein C-III-2. The Lancet 314: 667-671.

17. Maeda H, Hashimoto RK, Ogura T, Hiraga S, Uzawa H (1987) Molecular cloning of a human apoC-III variant: Thr 74----Ala 74 mutation prevents O-glycosylation. J Lipid Res 28: 1405-1409.

18. Maeda H, Uzawa H, Kamei R (1981) Unusual familial lipoprotein C-III associated with apolipoprotein C-III-O preponderance. Biochim Biophys Acta 665: 578-585.

19. Nakajima T, Jorde LB, Ishigami T, Umemura S, Emi M, et al. (2002) Nucleotide diversity and haplotype structure of the human angiotensinogen gene in two populations. Am J Hum Genet 70: 108-123.

20. Karthikeyan M, Shridevi V, Rose R, Anandan B, Singh KD, et al. (2013) Angiotensin Gene Polymorphisms (T174M and M235T) are Significantly Associated with the Hypertensive Patients of Tamil Nadu, South India. Int J Hum Genet 13: 201-207.

21. Schmidt S, Sharma AM, Zilch O, Beige J, Walla-Friedel M, et al. (1995) Association of M235T variant of the angiotensinogen gene with familial hypertension of early onset. Nephrol Dial Transplant 10: 1145-1148.

22. Pilbrow AP, Palmer BR, Frampton CM, Yandle TG, Troughton RW, et al. (2007) Angiotensinogen M235T and T174M gene polymorphisms in combination doubles the risk of mortality in heart failure. Hypertension 49: 322-327.

23. Mohana VU, Swapna N, Surender RS, Vishnupriya S, Padma T (2012) Genderrelated association of AGT gene variants (M235T and T174M) with essential hypertension--a case-control study. Clin Exp Hypertens 34: 38-44.

24. Iso H, Harada S, Shimamoto T, Sato S, Kitamura A, et al. (2000) Angiotensinogen T174M and M235T variants, sodium intake and hypertension among non-drinking, lean Japanese men and women. J Hypertens 18: 1197 1206.

25. Rubinsztein DC, Easton DF (1999) Apolipoprotein E genetic variation and Alzheimer's disease. a meta-analysis. Dement Geriatr Cogn Disord 10: 199209

26. Prada D, Colicino E, Power MC, Cox DG, Weisskopf MG, et al. (2014) Influence of multiple APOE genetic variants on cognitive function in a cohort of older men - results from the Normative Aging Study. BMC Psychiatry 14: 223.

27. Singh K, Singh VK, Agrawal NK, Gupta SK, Singh K (2013) Association of Toll-like receptor 4 polymorphisms with diabetic foot ulcers and application of artificial neural network in DFU risk assessment in type 2 diabetes patients. Biomed Res Int 2013: 318686.

28. Barøy T, Misceo D, Frengen $E$ (2008) [Structural variation in the human genome contributes to variation of traits]. Tidsskr Nor Laegeforen 128: 1951-1955.

29. Shastry BS (2009) SNPs: impact on gene function and phenotype. Methods Mol Biol 578: 3-22.

30. Kanehisa M, Goto S (2000) KEGG: kyoto encyclopedia of genes and genomes Nucleic Acids Res 28: 27-30.

31. Sambrook J, Green MR (1989) Molecular Cloning: A Laboratory Manual, Cold Spring Harbor Laboratory Press, New York.

32. Subbarayan PR, Sarkar M, Ardalan B (2002) Isolation of genomic DNA from human whole blood. Biotechniques 33: 123, 1234.

33. Mullis KB, Faloona FA (1987) Specific synthesis of DNA in vitro via a polymerase-catalyzed chain reaction. Methods Enzymol 155: 335-350.

34. Mullis KB (1990) The unusual origin of the polymerase chain reaction. Sci Am 262: 56-6, 64-5.

35. Stellwagen NC (2009) Electrophoresis of DNA in agarose gels, polyacrylamide gels and in free solution. Electrophoresis 30 Suppl 1: S188-195.

36. Johnson PH, Grossman LI (1977) Electrophoresis of DNA in agarose gels Optimizing separations of conformational isomers of double- and singlestranded DNAs. Biochemistry 16: 4217-4225.

37. Sanger F, Nicklen S, Coulson AR (1977) DNA sequencing with chainterminating inhibitors. Proc Natl Acad Sci U S A 74: 5463-5467. 
Citation: Cheekurhty AJP, Rambabu C, Kumar A (2015) Association of New Single Nucleotide Polymorphism with Type 2 Diabetes Mellitus. J Diabetes Metab 6: 530. doi:10.4172/2155-6156.1000530

Page 5 of 5

38. Thompson JD, Higgins DG, Gibbson TJ (1994) CLUSTAL W: improving the sensitivity of progressive multiple sequence alignment through sequence weighting,position-specific gap penalities and weight matrix choice. Nucleic Acids Res 22: 4673-4680.
39. http://alpha.life.nthu.edu.tw/ 92a52/homework/homework7/BOXSHADE.htm

40. Altschul SF, Gish W, Miller W, Myers EW, Lipman DJ (1990) Basic local alignment search tool. J Mol Biol 215: 403-410. 